The Age of Enligbtenment 


\author{
A volume \\ in \\ THE DOCUMENTARY HISTORY \\ of \\ WESTERN CIVILIZATION
}




\title{
THE AGE OF ENLIGHTENMENT
}

\author{
edited by \\ Lester G. Crocker
}

Macmillan Education 1969 
THE AGE OF ENLIGHTENMENT

Introduction, editorial notes, translations by the editor, and compilation Copyright (C) 1969 by Lester G. Crocker

Softcover reprint of the hardcover ist edition 1969 978-o-333-05504-5

First published in the United States 1969

First published in the United Kingdom by Macmillan \& Co 1969

Published by

MACMILLAN \& CO LTD

Little Essex Street London wc 2

and also at Bombay Calcutta and Madras

Macmillan South Africa (Publishers) Pty Ltd Johannesburg

The Macmillan Company of Australia Pty Ltd Melbourne

Gill and Macmillan Ltd Dublin

ISBN 978-1-349-0037I-6 ISBN 978-1-349-00369-3 (eBook)

DOI 10.1007/978-I-349-00369-3 


\section{Contents}

Introduction 1

I The Human Situation 31

1. Bayle, Answer to the Questions of a Provincial 32

2. Mandeville, The Fable of the Bees 33

3. La Mettrie, Man a Macbine 35

4. Rousseau, Discourse on the Origin of Inequality 37

5. Helvétius, On Man 45

6. Voltaire, Candide and Pbilosopbical Dictionary 47

7. Diderot, Rameau's Nepbew and Refutation of Helvétius, On Man 54

8. D'Holbach, Universal Morality, or the Duties of Man Founded on His Nature

9. De Sade, Philosopby in the Boudoir 68

II The Problem of Evil 72

10. Bayle, Manicbeans 73

11. Leibniz, Theodicy 76

12. Shaftesbury, The Moralists, $A$ Rhapsody 81

13. Voltaire, The Lisbon Eartbquake 83

14. Rousseau, Letter to Voltaire 90

15. De Sade, Philosopby in the Boudoir 93

III Science and Materialism 97

16. La Mettrie, Man a Macbine 98

17. Buffon, Discourse on Studying and Treating Natural History and The Epochs of Nature 104

18. Diderot, D'Alembert's Dream 111

$\begin{array}{ll}\text { IV Morals } & 120\end{array}$

19. Bayle, Historical and Critical Dictionary 123

20. Hume, Treatise of Human Nature 124

21. Adam Smith, The Theory of Moral Sentiments 133 
22. La Mettrie, Preliminary Discourse and Discourse on Happiness

23. Helvétius, $O n$ the Mind and $A$ Treatise on Man

24. Diderot, Natural Right; Rameau's Nephew; D'Alembert's Dream; and Elements of Physiology $\quad 150$

25. D'Holbach, $A$ System of Nature

26. Voltaire, Treatise on Metaphysics and Just and Unjust

27. Kant, Fundamental Principles of the Metaphysic of Morals

28. De Sade, Juliette, or the Prosperities of Vice

V Politics

29. Mandeville, "An Essay on Charity, and Charity Schools"

30. Montesquieu, The Spirit of the Laws

31. Linguet, Theory of Civil Laws, or Fundamental Principles of Society

32. Morelly, Code of Nature

33. Helvétius, $O n$ the Mind and $A$ Treatise on Man

34. Rousseau, Political Economy; The Social Contract; $A$ Constitution for Corsica; and On the Government of Poland

35. The Encyclopedia, "Property" and "Government"

36. Mercier, The Year 2440-Dream If There Ever Was One

37. D'Holbach, Etbocracy, or Government Founded on Morals

38. Restif de la Bretonne, The Australasian Discovery, by a Flying-Man, or the French Daedalus

39. Diderot, Observations on the Drawing Up of Laws

40. Madison, The Federalist

41. Jefferson, Letters to Colonel Edward Carrington and John Adams

VI Humanitarianism

42. Voltaire, Pbilosopbical Dictionary

43. Beccaria, An Essay on Crimes and Punishments

45. The Encyclopedia, "Philosophy" 
46. Franklin, Letter to Joseph Priestley 294

47. Gibbon, The Decline and Fall of the Roman Empire 295

48. Kant, Project for a Perpetual Peace 301

49. Condorcet, Sketch of a Historic Tableau of the Progress of the Human Mind

50. Malthus, An Essay on the Principle of Population 311

Chronology

321

General Works on the Age of Enlightenment

Index 